\title{
気体流量輸送係数による沿岸砕波带気液界面での 気体輸送評価法の提案
}

\author{
角野昇八*・関本武史**・日引俊***
}

\begin{abstract}
大気中の二酸化炭素ガスの海洋への溶解の速度などについてはまだまだ未解明の点があり，地球温暖化メカニズムの解明 もその面では十分には進んでいない. 本研究では, 沿岸砕波帯での気体輸送現象の解明を目的とするが, 従来の研究におけ るようには，気体輸送速度相当の気体輸送係数で現象を評価しようとするものではなく，それに曝気面積を乗じた形の気体 流量輸送係数で評価することを新たに提案するものである. 本研究ではさらに，造波水槽内の緩斜面上での砕波から得られ たデータ，および新たに得られた連行気泡特性の種々のデータに基づいてそのことの妥当性を検証し，さらに気体流量輸送 係数の実用的評価法を提案する.
\end{abstract}

\section{1. 緒言}

大気中の二酸化炭素ガスの海洋への溶解の速度 (大気/ 海洋気体輸送速度）あるいはその海洋吸収量などについ てはまだまだ末解明の点があり，したがって地球温暖化 メカニズムの解明もその面では十分には進んでいない現 状にある。この理由から, 大気/海洋気液界面での気体輸 送現象解明を目的とする研究が様々な側面から盛んに行 われている，著者らもこれまで，沿岸域砕波带における 気液界面を対象として, そこでの気体輸送現象には砕波 連行気泡が大きく関与しているとの立場に立って, 酸素 を対象とした一連の実験的研究を行ってきた（たとえば 角野ら，2001). 大気/海洋気体輸送速度はシュミット数 を介して正規化できるので, 酸素を対象とした成果は他 の気体にも応用することが出来る.

この種の研究に扔ける究極の目的は, 気液界面での気 体輸送速度に相当する気体輸送係数 $k_{L}$ の評価である.こ の係数は, 実験から直接求められるいわゆる再曝気係数 $k_{2}$ と

$$
k_{L}=(V / A) k_{2}
$$

で関係づけられている。ここに $V$ は曝気（に関わる）容 積，Aは曝気(に関わる)面積である。したがって， $k_{2}$ か ら $k_{L}$ を評価しようとする場合には, 曝気面積や曝気容積 が正確に見積もられていることが前提となるが, 沿岸砕 波帯での気体輸送現象の場合には特に曝気面積の評価に 困難さがあり，著者らもそれを十分には解決できていな い現状にあった，ところで，このことと，沿岸砕波帯で の気体輸送現象の特徵を考元合わせるとき, 気体輸送速 度 $\left(k_{L}\right)$ よりもむしろ気体流量輸送係数 $\left(k_{L} A\right)$ で評価す る方が現象に則して合理的であるし，また評価が容易で あると考えた。

本研究は, 以上のような立場に立って, 沿岸砕波帯に おける気体流量輸送係数の概念を提案するとともに, 造

* 正会員 工 博 大阪市立大学教授大学院工学研究科都市系専攻

** 正会員 修(工) 大阪府䇾屋川水系改修工営所

*** 工 博 京都大学原子炉実験所助教授
波水槽内の緩斜面上で生じさせた砕波を用いた再曝気係 数 $k_{2}$ の既往のデータ, および新たに得られた連行気泡特 性の種々のデー夕に基づいて，その妥当性を検証し，ま たその実用的な評価法を提案するものである.

\section{2. 沿岸砕波帯における気体流量輸送係数の概 念と提案}

沿岸砕波帯での大気/海中気体輸送現象を考え,さらに 気体輸送は連行気泡あるいは砕波によって激しく乱れた 水面を介して主として生じていると考えるとき，その曝 気面積 $A$ の評価は困難であったとしても, 曝気容積 $V$ は 砕波線と海底, 汀線で囲まれる部分の容積で評価できる として不合理は生じないであろう。また，取り込まれた 気体はさらに，その容積部分をソースとして，砕波線下 の面を通して砕波帯の沖側の非砕波域に拡散・移流して ゆくと考えることができょう（図一1参照）。

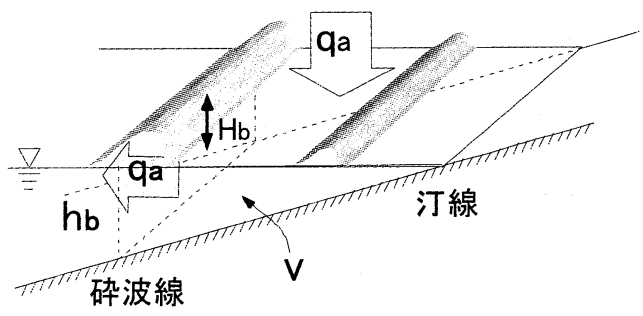

図一1 沿岸破波帯での気液界面気体輸送

現象のこのような見方が正しいものとすれば，曝気面 積を通して輸送される気体の速度そのものよりも, むし 万気体流量輸送係数 $\left(A k_{L}=V k_{2}\right)$ を知るほうが有用であ り, 現象の理解も容易となろう。

\section{3. 模型緩傾斜面上砕波域での気体流量輸送係 数の評価}

前章の考察より，造波水槽内の緩斜面上で生じさせた 砕波から得られた再曝気係数 $k_{2}$ の既往の実験デー夕お よび新たに得られた連行気泡特性のデー夕に基づいて, 
実験的ならびに半理論的に気体流量輸送係数を評価し， 両者の比較よりその基本的妥当性を検証する.

\section{（1）実験值に基づく気体流量輸送係数の值}

造波水槽内の緩斜面上で生じさせた砕波から得られた 再曝気係数 $k_{2}$ の既往の実験データを用い，また式 (1) の関係式を用いて気体流量輸送係数 $\left(A k_{L}=V k_{2}\right)$ の実験 值を求めた.ここで, 再曝気係数 $k_{2}$ には, 高さ $60 \mathrm{~cm}$, 幅 $50 \mathrm{~cm}$, 長さ $20 \mathrm{~m}$ で，その端部に $1 / 10$ あるいは $1 / 20$, $1 / 30$ の勾配を設けた造波水槽内で周期と波高の条件を 変えて得た実験值（角野ら，1996）を用い, また曝気容 積 $V$ には砕波線と海底，汀線で囲まれる容積の值を用い た。ただし，砕波波高 $H_{b}$ と砕波水深 $h_{b}$ は砕波指標から 今回新たに求めなおした，また，実験で用いた水は真水 であった。

\section{（2） Eckenfelder の式に基づく気体流量輸送係数の 理論值}

既報（角野ら，2000）のように，Eckenfelder（1959） が提案した散気槽内での気泡群による物質輸送係数 $k_{L}$ を算定するための式を変形すれば

$$
k_{L}=C l^{2 / 3} Q_{a} / A d_{m} S_{c}^{1 / 2}
$$

を誘導することができる．ここに，Cは係数， $l$ は散気 板深さ, $Q_{a}$ は混入気泡流量, $A$ は曝気面積, $d_{m}$ は気泡平 均径, $S_{c}$ はシュミット数である.この式に基づく気体流 量輸送係数はしたがって，

$$
A k_{L}=C l^{2 / 3} Q_{a} / d_{m} S_{c}^{1 / 2}
$$

と表すことができる．ここでこの式を沿岸砕波に適用す るために, $Q_{a}$ を単位時間当たり砕波連行気泡容積とし, また $l$ を砕波高 $H_{b}$ 程度と評価すると, Eckenfelder の式 に基づく気体流量輸送係数の理論式として次式を得る.

$$
A k_{L}=C^{\prime} H_{b}^{2 / 3} V_{g} / d_{m} S_{c}^{1 / 2} T
$$

ただしここに, $V_{g}$ は砕波による一周期間連行総気泡容積 であり， $T$ は波の周期である．また， $C^{\prime}$ は比例定数であ るが，その值は水底勾配によって変化することが考えら れる。
（3）気泡平均径および連行気泡容積測定のための実 験（角野ら，2003）

式（4）に基づいて気体流量輸送係数を評価するため には, 砕波による一周期間連行総気泡容積 $V_{g}$ および気 泡の平均径 $d_{m}$ が必要となる.これらについては, すでに シングルボイドプローブを用いて測定しているが（角野 ら, 2001), 今回新たにダブルボイドプローブを開発して 測定した.

a）シングルボイドプローブとダブルボイドプローブ

シングルボイドプローブ（SVP）の原理についてはす でに前論文（角野ら，2001）で述べている，今回新たに 開発したダブルボイドプローブ (DVP) の測定原理の基 本はSVP と同じであるが，そのプローブ部が近接した 2 本で構成されているので，2本のプローブの気泡通過時 間差とプローブ間隔より気泡移動速度を測定できる特長 を持っている. したがって, SVP 使用時に気泡移動速度 測定のために必要とされたビデオカメラ等は必要とされ ず，その使用が困難な現地での測定にきわめて有利とな る.

b) 平均気泡径

DVP を用いて, 球と仮定した気泡の平均径を求めた. 用いた造波水槽は高さ $60 \mathrm{~cm}$, 幅 $50 \mathrm{~cm}$, 長さ $20 \mathrm{~m}$ で,

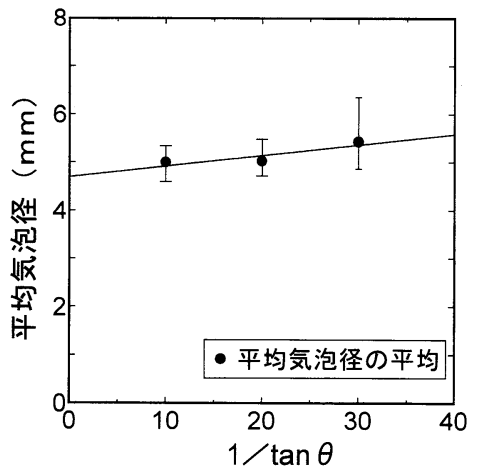

图一～平均気泡径の平均の水底勾配による変化

表一1 実験条件と実験結果

\begin{tabular}{c|c|c|c|c|c|c|c|c|c}
\hline $\begin{array}{c}\text { 水底勾配 } \\
\tan \theta\end{array}$ & $\begin{array}{c}\text { 周期 } \\
T[\mathrm{~s}]\end{array}$ & $\begin{array}{c}\text { 沖波波高 } \\
H_{0}^{\prime}[\mathrm{cm}]\end{array}$ & $\begin{array}{c}\text { 波形勾配 } \\
H_{0}^{\prime} / L_{0}\end{array}$ & $\begin{array}{c}\text { 破波波高 } \\
H_{b}[\mathrm{~cm}]\end{array}$ & $\begin{array}{c}\text { 破波水深 } \\
h_{b}[\mathrm{~cm}]\end{array}$ & 破波形式 & $\begin{array}{c}\text { 平均径 } \\
d_{m}[\mathrm{~mm}]\end{array}$ & $\begin{array}{c}\text { 連行気泡容積 } \\
V_{g}\left[\mathrm{~cm}^{3} / \mathrm{cm}\right]\end{array}$ & $\begin{array}{c}\text { 連行気泡表面積 } \\
A_{g}\left[\mathrm{~cm}^{2} / \mathrm{cm}^{\prime}\right]\end{array}$ \\
\hline \multirow{6}{*}{$1 / 30$} & 1.0 & 11.8 & 0.076 & 12.0 & 18.0 & 崩れ波 & 5.67 & 17.57 & 177.28 \\
& 2.0 & 8.3 & 0.013 & 12.2 & 14.0 & 巻き波 & 5.34 & 13.05 & 138.89 \\
& 1.0 & 7.8 & 0.050 & 8.0 & 11.7 & 崩れ波 & 6.29 & 6.10 & 53.71 \\
& 1.2 & 7.0 & 0.031 & 9.0 & 16.4 & 崩れ波 & 5.80 & 16.18 & 130.68 \\
& 1.2 & 4.3 & 0.019 & 6.0 & 8.4 & 巻き波 & 5.55 & 3.74 & 26.56 \\
& 1.0 & 6.1 & 0.039 & 7.0 & 8.5 & 崩れ波 & 5.07 & 2.56 & 19.56 \\
& 1.0 & 9.2 & 0.059 & 9.5 & 13.0 & 崩れ波 & 5.50 & 7.70 & 69.61 \\
& 1.1 & 7.6 & 0.040 & 8.8 & 13.0 & 崩れ波 & 5.02 & 7.99 & 74.77 \\
& 0.9 & 8.5 & 0.067 & 8.7 & 15.0 & 崩れ波 & 5.05 & 15.12 & 165.13 \\
& 1.0 & 10.7 & 0.068 & 10.4 & 17.7 & 崩れ波 & 4.94 & 17.22 & 166.05 \\
\hline
\end{tabular}


その端部に $1 / 10$ あるいは $1 / 20,1 / 30$ の木製勾配を設け, 周期と波高の条件を全 18 ケース変えて実験を行った。使 用した水は真水である。 その条件と結果を表一1に示す. また, 気泡径平均值の水底勾配による変化の様子を図-2 に示した。

表一1 あるいは図一 2 より,波浪条件に関わらず平均径 はほぼ同じで $5 \mathrm{~mm}$ 程度であり, SVP を用いて得られた 值 $5.5 \mathrm{~mm}$ (6 mm から既訂正) とほぼ同じであるあるこ とがわかる.水底勾配が $\tan \theta=1 / 30$ では, その時の平均 気泡径の平均は $d_{m}=5.4 \mathrm{~mm}$ である.ただ図一 2 に示す ように，平均気泡径の平均は水底勾配に関してわずかに 線形的に変化する傾向が見られる.

c）連行気泡容積

c-1) 平面局所気泡容積 $V_{g}^{\prime}$

連行気泡容積の求め方は基本的にSVPを用いた前回 と同様であるが，今回は砕波帯での确波現象の実態に則 してさらに厳密に評価した。

SVP あるいはDVP のデー夕からは, まず水槽内 2 次 元砕波帯の中の $\mathrm{VP}$ 設置点での空間局所ボイド率 $\phi^{\prime \prime}$ を 求めることが出来る.またこれとは別に, その VP 設置点 での気液二相の一波の通過時間 $t_{t}$ が求まり,さらにそれ にその地点での波速 $(C=\sqrt{g h})$ を乗じることにより, VP 設置点での気液二相の一波の通過距離 $l_{t}$ を求めること が出来る (図一 3 参照)。この $l_{t}$ はまた, 水槽幅方向の単 位幅，単位高さあたりのその高さでの気液二相一波の筒 状容積 $V_{t}$ でもある.このようにして得られた $V_{t}$ に先に 求めた空間局所ボイド率 $\phi^{\prime \prime}$ を乗じることにより，空間 局所的な気泡部容積 $V^{\prime \prime} g$ を求めることが出来る.すなわ ち

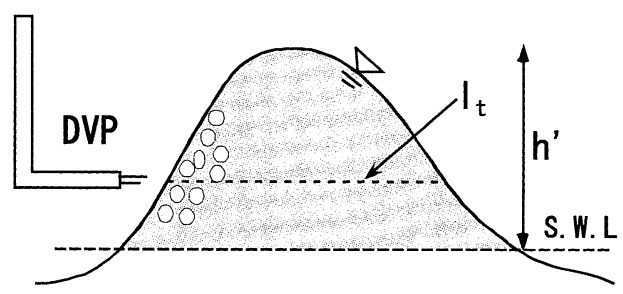

図一3 破波の中の DVP

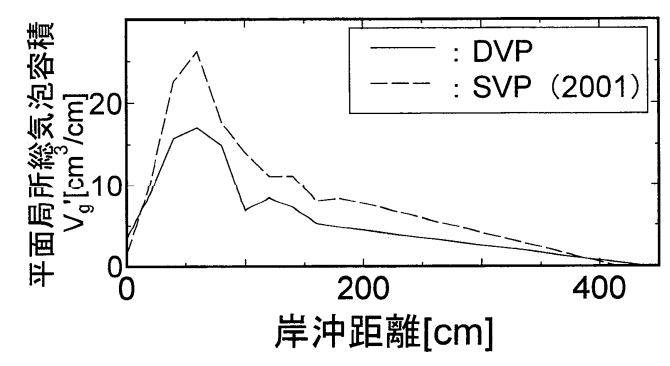

図-4 平面局所総気泡容積の分布 $\left(T=2.0 \mathrm{~s}, H_{0}^{\prime}=8.3 \mathrm{~cm}\right)$

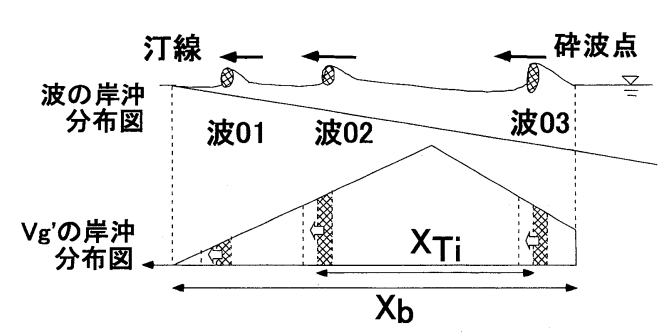

図一5 破波帯での破波と $V_{g}^{+}$の岸沖分布

$V_{g}^{\prime \prime}=\phi^{\prime \prime} V_{t}$

この空間局所気泡容積 $V_{g}^{\prime \prime}$ を鉛直方向に積分することに より, 平面局所気泡容積 $V_{g}^{\prime}$ を求めることが出来る.すな わち,

$$
V_{g}^{\prime}=\int_{0}^{h^{\prime}} V_{g}^{\prime \prime} d z
$$

静水面以下には気泡部はほとんど認められなかったの で, 積分は静水面以上水面までの高さとしている。この ようにして得られた平面局所気泡容積の砕波点から汀線 までの分布の例を示したものが図一4である. 図中には SVPによってすでに得られている值も示した。

c-2）一周期間総気泡容積 $V_{g}$

砕波線から汀線に至る砕波帯には複数の研波が存在す る.たとえば，図一5に示す状況では，砕波線で砕けだし た波 3 は波の一周期間に 2 まで進行し,またその間に, 2 にあった波は 1 まで進行する。砕波帯での砕波を介した 気体輸送はこれら複数の砕波で行われているはずであ り，その総和を考慮する必要がある．また，砕波帯を進 行する各研波はその過程で図一4, あるいは図一5 の下図 に示すような平面局所気泡容積の履歴を持つので，それ も考慮した評価が必要である。すなわち，波の 1 周期間 あたりの平均総気泡容積 $V_{g}$ は

$$
\begin{aligned}
V_{g}= & 1 / x_{0-1} \cdot \int V_{g}^{\prime} d x+1 / x_{1-2} \cdot \int V_{g}^{\prime} d x \\
& +1 / x_{2-3} \cdot \int V_{g}^{\prime} d x+\ldots \ldots \ldots \ldots \ldots \ldots \ldots \ldots
\end{aligned}
$$

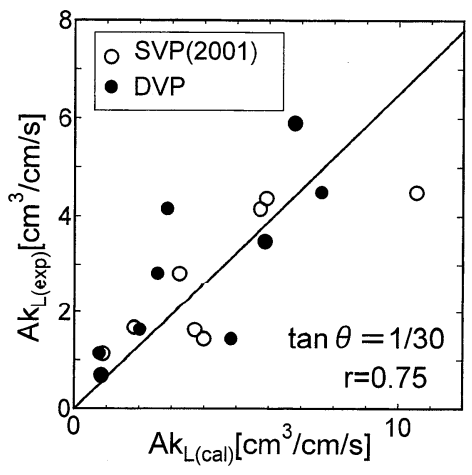

图一6 $A k_{L}$ の計算値と実験值の比較 
によらねばならない.ここに積分区間は, 図一5の例では 波 3 から波 2 まで, あるいは波 2 から 1 までであり, ま た $x_{2-3}$ などは, 波 2 と 3 の間の距離などである。このよ うにして求めた $V_{g}$ の結果も表一 1 に示した.

\section{(4) 理論式の妥当性の検証}

砕波連行気泡特性の実験值を式 (4) に代入して求め られる $A k_{L}$ の值の妥当性を検討するために, その值と, 再曝気実験から求められた $k_{2}$ および $V$ とから式 $(1)$ を 介して求められる $A k_{L}$ と比較した。図一6 は，水底勾配 が $\tan \theta=1 / 30$ の場合の $C^{\prime}=1$ とした式（4）による值 $A k_{L(\text { cal })}$ に対する式（1）による值 $A k_{L(\exp )}$ を表す。ただ し, $S_{c}=500$ とし $d_{m}$ は平均径の平均値 $(5.4 \mathrm{~mm})$ を用い た。図中にはSVPによる結果も示した。図一6に示すよ うに，両者の間には多少のばらつきが見られるものの， ほぼ線形的な関係が認められ，式 $(4)$ によって $A k_{L}$ を 評価できていると見ることができる，この結果より水底 勾配が $1 / 30$ の場合には $C^{\prime}=0.65$ と決定することがで き，またその関係は以下のようになる。

$$
A k_{L}=0.65 H_{b}^{2 / 3} V_{g} / d_{m} S_{c}^{1 / 2} T
$$

\section{4. 実用化に向けた理論式の改良}

式（8）によって $A k_{L}$ を評価できることを示せたが， 式 ( 8 ) の算定のためには一周期間連行総気泡容積 $V_{g}$ を 知る必要があり，そのままでは実用的ではない，そこで $V_{g}$ を波浪条件のみによって評価できるかどうか確認し た.

\section{（1）一周期間総気泡容積 $V_{g}$ と波浪条件との関係}

図一7 は, $1 / 10,1 / 20,1 / 30$ の水底勾配と種々の波浪条 件の下で, 砕波高 $H_{b}$ と砕波線と汀線で囲まれる面積 $A_{p}$ の積 $\left(H_{b} \times A_{p}\right)$ に対する $V_{g}$ の関係を示したものである. 両者の間には明確な線形関係が認められ， $V_{g}$ を $H_{b}$ と $A_{p}$ の積で表すことができることがわかる. $A_{p}$ はさらに, 単位幅あたり $h_{b} / \tan \theta$ ( $h_{b}$ は砕波水深) でもあるので, 図一7に示される関係は

$$
V_{g}=3.1 \times 10^{-3} H_{b} h_{b} / \tan \theta
$$

と表すことが出来る.

結局, 気体流量輸送係数は, 水底勾配が $\tan \theta=1 / 30$ の

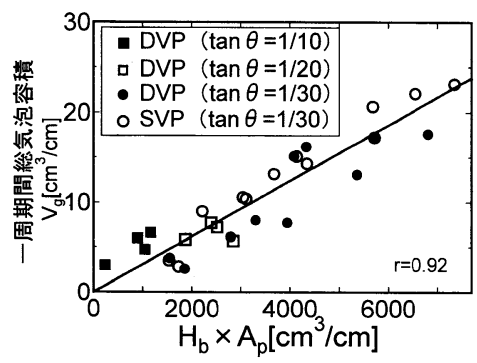

园一7 $V_{g}$ と $H_{b} \cdot A_{p}$ の関係

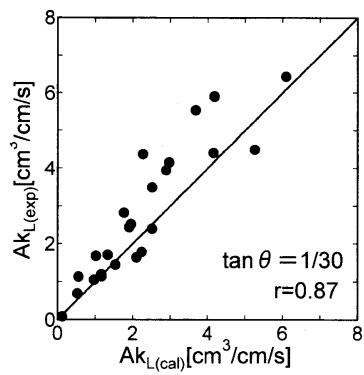

图一8 $A k_{L}$ の実用計算式による値と実験值の比較（ $\tan \theta=$ $1 / 30)$

場合

$$
A k_{L}=2.02 \times 10^{-3} H_{b}^{5 / 3} h_{b} /\left(T d_{m} S_{c}^{1 / 2} \tan \theta\right) \cdots(10)
$$

と表されることになる。

\section{（2）改良理論式の妥当性の検証}

$1 / 30$ の水底勾配で，種々の波浪条件にある既往の $k_{2}$ データによる気体流量輸送係数と, 同条件にある式(10) による同値の比較を図一 8 に示す．ただし，ここでも $d_{m}$ は $d_{m}=5.4 \mathrm{~mm}$ とし， $S_{c}=500$ とした. 図一8によれば, 計算値は実験值をわずかに過小評価する傾向にあること が認められる。このように若干の差違が生じた理由は, 図一6においては, SVP あるいはDVP による $V_{g}$ の特性 が明らかになっているケースのみについての比較であっ たのに対して，図一 $8 て ゙ は k_{2}$ データが得られている全

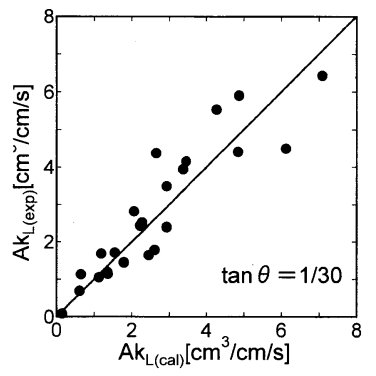

図一9 $A k_{L}$ の修正実用計算式による值と実験值の比較 $(\tan \theta=1 / 30)$

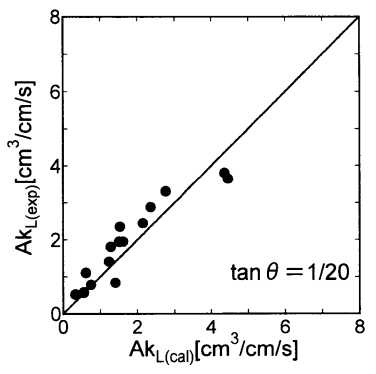

図-10 $A k_{L}$ の修正実用計算式による值と実験値の比較 $(\tan \theta=1 / 20)$ 


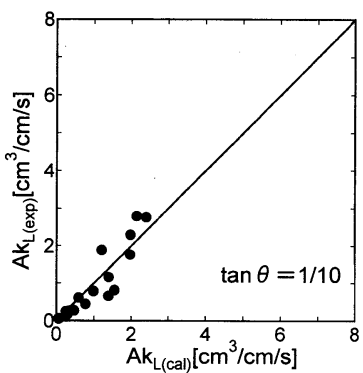

図一11 $A k_{L}$ の修正実用計算式による值と実験値の比較 $(\tan \theta=1 / 10)$

ケースについて比較したためであると考えられる。そこ で，式（10）の係数を改めて図-8のデータにべスト フィットするように定めた。 その結果，式（10）は

$$
A k_{L}=2.35 \times 10^{-3} H_{b}^{5 / 3} h_{b} /\left(T d_{m} S_{c}^{1 / 2} \tan \theta\right) \cdots(11)
$$

となった.また, 他の水底勾配のデー夕についても全デー 夕を検討した結果, 水底勾配が $1 / 20\left(d_{m}=5.0 \mathrm{~mm}\right)$ の場 合,

$$
A k_{L}=2.38 \times 10^{-3} H_{b}^{5 / 3} h_{b} /\left(T d_{m} S_{c}^{1 / 2} \tan \theta\right) \cdots(12)
$$

であり, $1 / 10\left(d_{m}=5.0 \mathrm{~mm}\right)$ の場合,

$$
A k_{L}=2.74 \times 10^{-3} H_{b}^{5 / 3} h_{b} /\left(T d_{m} S_{c}^{1 / 2} \tan \theta\right.
$$

となった.これらの水底勾配別の推算值と実験値の合致 の程度を図一9〜図-11に示す。

これらの図において実験值と計算值を比較したとき, その合致の程度が良いのは当然のことであるが, 計算式 による值と全実験データは偏ることなく合致していて, その妥当性と有用性が示されているといえよう。また， 図-12 は，3 種の水底勾配の全デー夕に対してべスト フィットするように係数を決定し，

$$
A k_{L}=2.33 \times 10^{-3} H_{b}^{5 / 3} h_{b} /\left(T d_{m} S_{c}^{1 / 2} \tan \theta\right) \cdots(14)
$$

で算定した計算値との比較である.ただし, $d_{m}=5.2 \mathrm{~mm}$ としている. 実験条件内の水底勾配に関係なく, 式(14) で $A k_{L}$ 值の全体的な評価が可能なことが示されている. また, この図から, 酸素の流量輸送係数は, 本研究の実 験条件下では数 $\mathrm{cm}^{3} / \mathrm{s} / \mathrm{cm}$ 程度であることがわかる.

\section{5. 結}

本研究では, 沿岸域砕波帯における気体輸送量の評価 を目的として，気体流量輸送係数の概念を提案するとと もに，その妥当性を検証した。ここで提案の気体流量輸 送係数による評価によれば, シュミット数と気泡平均径 のほか，海底勾配と波の周期，砕波高および砕波水深の 海底断面と波浪条件のみによって対象の沿岸域から沖合

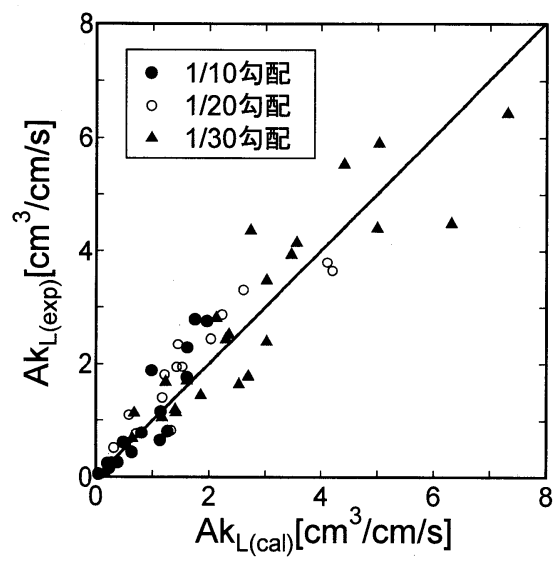

図-12 $A k_{L}$ の修正実用計算式による値と実験值の比較（全 ケース)

いに移流・拡散する気体の流量相当量を算定できること になり, 実用上有用な式ではないかと思われる.ただし， 本研究では塩水/淡水の違いによる影響, あるいは縮尺影 響などが考慮されていないので，そのまま直ちに現地海 岸へ適用するにはまだ無理がある。しかしながら，これ らの点が解決されれば，気体流量輸送係数の概念を適用 することにより，たとえばある湾域での年間平均再曝気 ポテンシャルあるいは二酸化炭素ガス吸収量などの算定 が可能となり, 現象解明に大きな足がかりとなるものと 考えられる。

なお，本研究は文部科学省科学研究費補助金（課題番 号 12305031）の補助を受けて行われた.ここに記して謝 意を表する。

\section{参 考 文 献}

角野昇八・杉田智行・合田 巧 (1996)：海底勾配の影響を考虑 した海浜砕波の酸素取り込み機能に関する総括的考察, 海岸 工学論文集, 第 43 巻, 1211-1215.

角野昇八・館川徹也・竹村健治・山岸達也 (2000)：沿岸砕波に おける混入気泡容積特性とその再曝気現象に与える効果, 海 岸工学論文集, 第 47 巻, 136-140.

角野昇八・山岸達也・日引 俊・関本武史 (2001)：ボイドプロー ブを用いた砕波連行気泡特性の解析とそれに基づく気体輸 送現象の解析, 海岸工学論文集, 第 48 巻, 71-75.

角野昇八・鈴木琢磨・関本武史・日引 俊 $(2003)$ ：砕波連行気 泡特性測定のためのダブルボイドプローブの開発とその適 用性の検討, 海岸工学論文集, 第 50 巻, pp. 1406-1410.

Eckenfelder Jr., W. W. (1959): Absorption of Oxygen from Air bubbles in Water, J. Sanitary Eng. Div., Proc. ASCE, 89-99. 